\title{
面圧分布の変動を考慮したブレーキ鳴き低減のための ディスクブレーキの構想設計法*
}

\author{
松島 徹** 泉 井一 浩*** 西 脇 眞 二*** \\ A Conceptual Design Method of Disc Brake Systems for Reducing Brake \\ Squeal Considering Pressure Distribution Variations \\ Toru MATSUSHIMA, Kazuhiro IZUI and Shinji NISHIWAKI
}

\begin{abstract}
This paper proposes a design optimization method for disc brake systems that specifically aims to reduce brake squeal, with robustness against changes on contact surface pressure distribution, based on the concept of First Order Analysis. First, a simplified analysis model is constructed in which a pressure distribution parameter is introduced, and the relationships between the occurrence of brake squeal and the characteristics of various components is then clarified, using the simplified model. Next, a new design performance measure that takes pressure distribution changes over the contact surfaces into account is proposed for evaluating brake squeal performance, and an optimization problem is formulated in which this performance measure is used as a constraint condition, with maximization of the brake-pad contact area as the objective function. The optimization problem is solved using a genetic algorithm. The proposed method is then applied to design problems and a disc brake system is constructed based on an optimal solution. Finally, experimental studies are conducted to confirm that the proposed method can yield optimal designs that minimize brake squeal and are robust against pressure distribution changes.
\end{abstract}

Key words: conceptual design, design optimization, first order analysis, CAE, numerical analysis, disc brake, minimizing brake squeal

\section{1. 緒言}

機械製品の構想設計の充実を図る方法として, First Order Analysis $(\mathrm{FOA})^{1)}$ が提案され, 実際の機械部品の設計・開発に広 く適用されつつある. FOA は, 設計者に設計要因と性能を, 力 学的に筋道を立てて理解可能な物理量を提供し，構想設計段階 における意思決定を支援することを目的とする. FOA は，単な る現象解明ではなく, 機能が力学的に明確で, 構造的意味や設 計指針が得やすい簡易力学モデルによる評価と, 設計指針を与 える設計評価尺度の構築を基本とする.

本研究では, 自動車に多用されているディスクブレーキの設 計を対象に, 上で述べた FOA の概念に基づき, ブレーキの基本 性能の一つであるブレーキ鳴きの低減を目的に構想設計法を開 発している.このブレーキ鳴きは，ブレーキディスク（以下， ディスクと略す）とパッドに間に生じる摩擦力が, ある臨界值 を越えた状態において発生すると考えられ, ディスクとパッド 間の摩擦係数の変化に着目した多くの現象解明 ${ }^{2) ~ 5) か ゙ さ れ て い ~}$ るが，これらは現象の解明だけに留まっている.

これらの現象解明に対して, Millner ${ }^{6} は$, 自励振動現象の観点 から, 固有值に基づく安定判別により, ブレーキ鳴きの発生有 無を判別する方法を提案している. この Millner の考え方に基づ

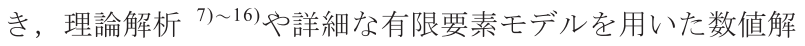
析 ${ }^{17) ~ 19)}$ によりブレーキ鳴きの現象解明と性能評価を可能とす る方法が幾つか提案されている. 特に, 有限要素法に基づく方 法は，構成部品の詳細設計案の評価を可能とし，ブレーキシス テムの性能評価に多用されている. しかし, この方法は, 構成

* 原稿受付 平成 22 年 10 月 15 日

** 正会員卜ヨタ自動車（株）（静岡県裾野市御宿 1200）

*** 正 会員 京都大学大学院 (京都府京都市左京区吉田本町)
部品の詳細形状を表現した有限要素モデルを必要とするため, 通常, 設計諸元が決定された詳細設計段階でのみ利用可能な方 法に留まっている，さらに，モデル自体の自由度が過度に多い ため, 性能の本質的な理解を行うことが難しく, それゆえに, 抜本的に設計変更指針も得ることは困難である.

他方, Millner の考え方に基づき, 簡易な力学モデルを用いた 力学解析も多く行われている ${ }^{8) ~ 14)}$. 前報では, 構想設計を充実 するための基本的な考え方である FOA の考え方のもと，このよ うな簡易な力学モデルを用いたブレーキ鳴き低減を目指した構 想設計法を提案した。 寸なわち，簡易モデルによりブレーキ鳴 きの現象を解明するとともに, 摩擦面の摩擦係数と接触剛性の 両方の変動を考慮した新しい設計評価尺度 ${ }^{20)}$ を構築し, それに よりブレーキの構想設計法の開発した. これにより, 摩擦面の 摩擦係数と接触岡性の変動が生じても, ブレーキ鳴きが生じな い構想設計の方策を提言できるようになった.

しかしながら，ディスクとパッド間の面圧分布の変動に関し ては, 摩擦面の接触剛性の変動を生じさせ, ブレーキ鳴きの発 生に大きく影響を与える因子であるにも関わらず, 過去の研究 事例や前報では考虑されていない, 寸なわち, 実際のディスク ブレーキでは, ディスクとパッド間の面圧分布は, ディスクブ レーキの使用条件, すなわちパッドをディスクに押付ける力, ディスクとパッド間の摩擦力, ディスクとパッドの温度, パッ ドの摩耗などによって変動することは, 多くの実験によりわか っているうえ, 文献 11112)14212122)において報告されているが，それ に関する考察結果は皆無に近い. しかし, このような変動のブ レーキ鳴きに与える影響は大きく, 構想設計時に想定した面圧 分布ではブレーキ鳴きの発生しない摩擦面の摩擦係数と接触剛 性の設定であっても, 面圧分布が変動することによりブレーキ 鳴きを生じることがある.このような問題を解決するためには, 
面圧分布の変動によって生じる接触剛性分布の変動に対して, ブレーキ鳴き性能が変化しないロバスト性の高いブレーキシス テムを開発することが必要となる.

そこで, 本論文では, FOA の考え方のもと, 従来の研究事例 では，考慮されていなかったディスクとパッド間の面圧分布の 変動に対するブレーキ鳴き性能のロバスト性を考慮した, 新し いブレーキシステムの最適構想設計法を開発する. 以下 2 章で は，まずディスクとパッド間の面圧分布の変動を検討するため, 面圧分布の変動に対する摩擦面の接触剛性の変動勾配を表す係 数 $\eta$ を新たに提案し，不均一な面圧分布を考慮可能な簡易モデ ルを用いたブレーキ鳴き解析のための定式化を行う．3 章では, 2 章の定式化に基づくブレーキ鳴き解析法を用いて, 不確定因 子たる摩擦係数と, 接触剛性, さらに面圧分布の変動により生じ る接触剛性分布の変動と, ブレーキ鳴き性能の関係を考察寸る. さらに, その考察結果に基づき, 面圧分布の変動に対するロバ スト性を考慮した新しい設計評価尺度を構築するとともに，そ れに基づき最適設計問題を定式化する．4 章では，具体的な設 計例に対して, 最適設計問題を解き最適解を求めるとともに, 実験結果との比較を行うことにより, 方法論の妥当性と有効性 を検証する。

\section{2. ブレ一キ鳴き解析法}

\section{1 簡易力学デル}

ここでは，FOA の考え方に基づき，設計指針を与える簡 易モデルを構築する．本研究でブレーキ鳴き解析に用いる 簡易モデルは，基本的には前報 ${ }^{20)} に て$ 構築したモデルと同 様で, ブレーキ鳴きの振動数が $5 \mathrm{kHz}$ 以下で, 振動モードが, ディスクは面外方向の曲げ変形，パッドは剛体運動である, 低周波数鳴きと呼ばれるブレーキ鳴きを対象としている。

図 1 に，本研究で用いる簡易モデルを示す．同図に示した ように，簡易モデルは，ディスク，アウターパッド，イン ナーパッド,マウンティングブラケットで構成される.なお, マウンティングブラケットを支持するサスペンションブラケッ

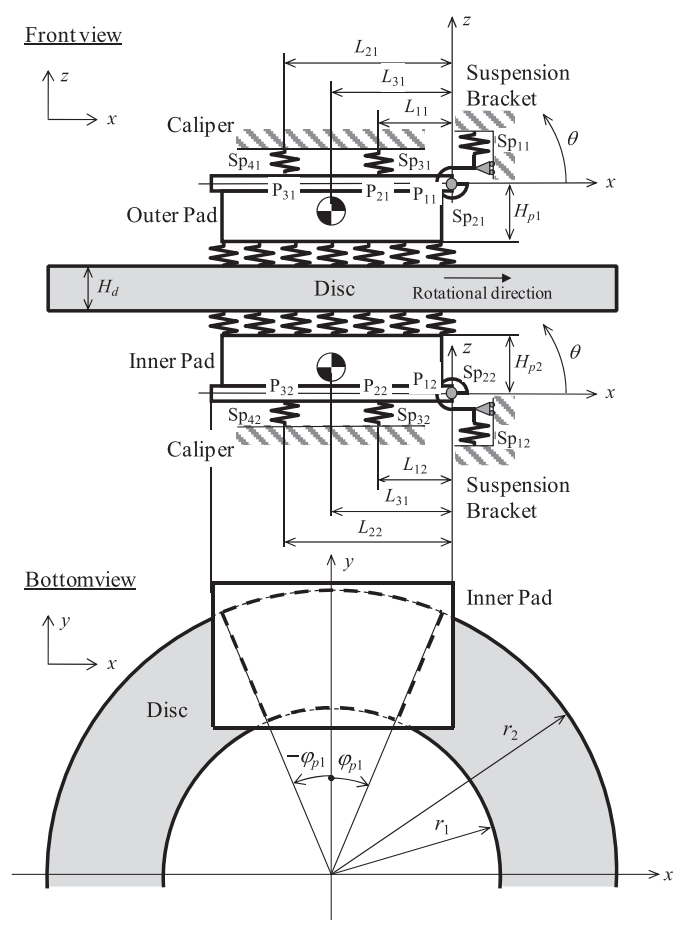

Fig. 1 Simplified brake analysis model
トについては，ブレーキ鳴き発生時の振幅が，マウンティング ブラケットの振幅と比較し十分小さいことから，このモデルで は考慮していない

また，ディスクは，図 2 に示ように，モデルの簡易化ため一 様厚さで, 内周 $\left(r=r_{1}\right)$ が完全固定され, 外周 $\left(r=r_{2}\right)$ が自由端の 弾性体の円板とし，ディスクとアウターパッド，インナーパ ッドは間の面接触は分布ばねで表現する。また，車両外側 に配置されるアウターパッドは点 $\mathrm{P}_{11}$ で，並進および回転方 向の支持剛性を表現する二つのばね要素 $\mathrm{Sp}_{11}, \mathrm{Sp}_{21}$ で表現し た，マウンティングブラケットに支持される．同様に，車両 内側に配置されるインナーパッドは点 $\mathrm{P}_{12}$ で，並進および回 転方向の支持剛性を表現する二つのばね要素 $\mathrm{Sp}_{12}, \mathrm{Sp}_{22}$ で表 現した，マウンティングブラケットに支持される. そして, アウターパッドとインナーパッドとも，それぞれの支持点 を中心に, $z$ 方向に並進, $\theta$ 方向に回転する剛体運動をする ものとする．さらに，アウターおよびインナーパッドが $Z$ 方向にキャリパで支持されている状況を表現するため，ア ウターパッドをばね要素 $\mathrm{Sp}_{31}, \mathrm{Sp}_{41}$, インナーパッドをばね 要素 $\mathrm{Sp}_{32}, \mathrm{Sp}_{42}$ で支持する. なお, 本簡易モデルの解析自由 度は，後述するように 5 自由度もつことになる．

通常，安定したブレーキ性能を得るために，キャリパは，パッ ドをディスクに均一な面圧で押付けるように設計されることが多 い. しかし，制動時にパッドに作用する摩擦力を支持するパッド の支持位置は, 摩耗によるパッド厚さの減少を考慮し, 摩擦面に 対して $z$ 方向に $H_{p 1}, H_{p 2}$ だけオフセットしている. この位置で パッドは支持されるため，モーメントに関する釣り合い条件から 実際にはパッドには摩擦力による回転モーメントが図 3 (a)のよ うに作用寸る.この結果, ディスクとパッド間の接触面圧は, $x$ 方 向に関して不均一で，リーディング側が高くなり，パッドのリー ディング側の摩耗量が増加する．この偏摩耗が大きくなると，ピ ストンとパッド接触位置はトレーリング側に移動し, 図 3 (b) のよ うに，ディスクとパッドの接触面圧は，トレーリング側が高くな り，トレーリング側の摩耗量が増加する．さらに，トレーリング 側の摩耗量が増加すると, ピストンとパッドの接触位置は, リー ディング側に移動し, 再びリーディング側の接触面圧が高くなり, リーディング側の摩耗量が増加する. 以上のように, ディスクと パッド間の面圧分布はパッドの摩耗により大きく変動する．本研 究では，この面圧分布と変動を表現可能な簡易モデルの運動方程 式を定式化する.

\section{2 面圧分布を考慮した簡易モデルの運動方程式}

図 2 に示寸ように, ディスクの中心を原点とし, 半径方向を $r$, 円周方向を $\varphi$, 面外方向を $z$ とした座標系を設定寸る. ディスク の内径は $r_{1}$, 外径を $r_{2}$ とし, 内径上の境界を完全固定する. デ イスクの厚さを $H_{d}$, 質量密度を $\rho$, ヤング率を $E$, ポアソン 比を $v$, 面外方向の変位を $w_{d}$ として, ディスクの運動エネルギ 一 $T_{d}$ と，ポテンシャルエネルギーを $V_{d}$ を求めれば，それぞれ次

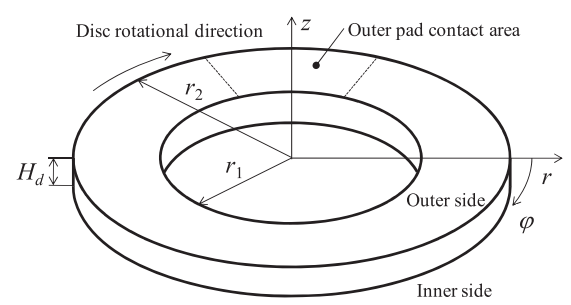

Fig. 2 Coordinate system and disc dimensions 


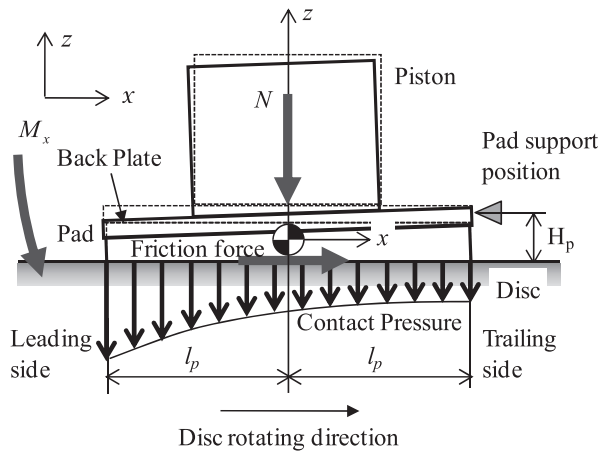

(a) A case when contact pressure at leading side is large

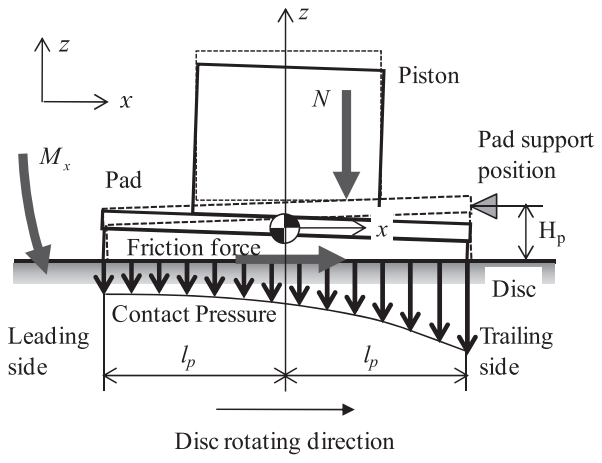

(b) A case when contact pressure at trailing side is large

Fig. 3 Non-uniform contact pressure distribution

式となる.

$$
T_{d}=\frac{1}{2} \int_{r_{1}}^{r_{2}} \int_{0}^{2 \pi} \rho H_{d} \dot{w}_{d}^{2} r d r d \varphi
$$

$$
V_{d}=\frac{1}{2} \int_{r_{1}}^{r_{2}} \int_{0}^{2 \pi} D\left[\left(\nabla^{2} w_{d}\right)-2(1-v) \frac{\partial^{2} w_{d}}{\partial r^{2}}\left(\frac{1}{r} \frac{\partial w_{d}}{\partial r}\right.\right.
$$$$
\left.\left.+\frac{1}{r^{2}} \frac{\partial^{2} w_{d}}{\partial \varphi^{2}}\right)+2(1-v)\left\{\frac{\partial}{\partial r}\left(\frac{1}{r} \frac{\partial w_{d}}{\partial \varphi}\right)\right\}^{2}\right] r d r d \varphi
$$

ここで,

$$
\nabla^{2}=\frac{\partial^{2}}{\partial r^{2}}+\frac{1}{r} \frac{\partial}{\partial r}+\frac{1}{r^{2}} \frac{\partial^{2}}{\partial \varphi^{2}}
$$

$D$ はディスクの曲げ剛性で, 次式で求められる.

$$
D=\frac{E H_{d}{ }^{3}}{12\left(1-v^{2}\right)}
$$

いま, ディスクの変位 $w_{d}$ を次式のように, 半径方向 $r$, 円周方 向 $\varphi$, 時間 $t$ に関して変数分離する.

$$
w_{d}(r, \varphi, t)=w_{d r}(r) w_{d \varphi}(\varphi) q_{d}(t)
$$

なお, 円周方向の成分 $w_{d \varphi}(\varphi)$ に関しては, 次式が成り立つとす る.

$$
w_{d \varphi}(\varphi)=\cos N \varphi
$$

ここで, $N$ は対象としている振動モードにおける節直径の数であ る.上式を式(1),式(2)に代入すれば，次式となる.

$$
T_{d}=\frac{1}{2} \rho H_{d}\left(\int_{r_{1}}^{r_{2}} r\left(w_{d r}(r)\right)^{2} d r \int_{0}^{2 \pi}\left(w_{d \varphi}(\varphi)\right)^{2} d \varphi\right)\left(\dot{q}_{d}(t)\right)^{2}
$$

$$
\begin{aligned}
V_{d} & =\frac{1}{2} D\left\{\int_{r_{1}}^{r_{2}} \frac{1}{r}\left(\left(w_{d r}^{\prime}(r)\right)^{2}+2 v r w_{d r}^{\prime}(r) w_{d r}^{\prime \prime}(r)+r^{2}\left(w_{d r}^{\prime \prime}(r)\right)^{2}\right) d r\right. \\
& \times \int_{0}^{2 \pi}\left(w_{d \varphi}(\varphi)\right)^{2} d \varphi+2(1-v) \int_{r_{1}}^{r_{2}} \frac{1}{r^{3}}\left(w_{d r}(r)-r w_{d r}^{\prime}(r)\right)^{2} d r \\
& \times \int_{0}^{2 \pi}\left(w_{d \varphi}^{\prime}(\varphi)\right)^{2} d \varphi+\int_{r_{1}}^{r_{2}} \frac{1}{r^{3}}\left(w_{d r}(r)\right)^{2} d r \int_{0}^{2 \pi}\left(w_{d \varphi}^{\prime \prime}(\varphi)\right)^{2} d \varphi \\
& +\int_{r_{1}}^{r_{2}} \frac{2}{r^{2}} w_{d r}(r)\left(w_{d r}^{\prime}(r)+v r w_{d r}^{\prime \prime}(r)\right) d r \\
& \left.\times \int_{0}^{2 \pi} w_{d \varphi}(\varphi) w_{d \varphi}^{\prime \prime}(\varphi) d \varphi\right\}\left(q_{d}(t)\right)^{2}
\end{aligned}
$$

次に, アウターパッドの運動エネルギー $T_{p 1}$ とポテンシャ ルエネルギーを定式化する，アウターパッドの質量を $m_{p 1}$, 慣性モーメントを $I_{p 1}$ とし, 四 1 に示す $z$ と $\theta$ 方向の変位を $w_{p 1}$, $\theta_{p 1}$ とする.ささらに，ばね要素 $\mathrm{Sp}_{11}, \mathrm{Sp}_{21}, \mathrm{Sp}_{31}, \mathrm{Sp}_{41}$ のばね 定数を $k_{b 11}, k_{b 21}, k_{c 11}, k_{c 21}$ とすると, アウターパッドの運動お よびポテンシャルエネルギー $T_{p 1}, V_{p 1}$ は, 次式となる.

$$
\begin{aligned}
& T_{p 1}=\frac{1}{2} m_{p 1} \dot{w}_{p 1}{ }^{2}+\frac{1}{2}\left(m_{p 1} L_{31}{ }^{2}+I_{p 1}\right) \dot{\theta}_{p 1}{ }^{2} \\
& V_{p 1}=\frac{1}{2} D_{o p 1} w_{p 1}{ }^{2}-D_{o p 2} w_{p 1} \theta_{p 1}+\frac{1}{2} D_{o p 3} \theta_{p 1}{ }^{2}
\end{aligned}
$$

ここで,

$$
D_{o p 1}=k_{b 11}+k_{c 11}+k_{c 21}
$$

$$
D_{o p 2}=k_{c 11} L_{11}+k_{c 21} L_{21}
$$

$$
D_{o p 3}=k_{b 21}+k_{c 11} L_{11}{ }^{2}+k_{c 21} L_{21}^{2}
$$

同様に, インナーパッドの $z$ と $\theta$ 方向の変位を $w_{p 2}, \theta_{p 2}$, 質 量を $m_{p 2}$, 慣性モーメントを $I_{p 2}$, ばね要素 $\mathrm{Sp}_{12}, \mathrm{Sp}_{22}, \mathrm{Sp}_{32}$, $\mathrm{Sp}_{42}$ のばね定数を $k_{b 12}, k_{b 22}, k_{c 12}, k_{c 22}$ とすると, インナーパ ッドの運動およびポテンシャルエネルギー $T_{p 2}, V_{p 2}$ は, 次式とな ろ.

$$
\begin{aligned}
& T_{p 2}=\frac{1}{2} m_{p 2} \dot{w}_{p 2}{ }^{2}+\frac{1}{2}\left(m_{p 2} L_{32}{ }^{2}+I_{p 2}\right) \dot{\theta}_{p 2}{ }^{2} \\
& V_{p 2}=\frac{1}{2} D_{i p 1} w_{p 2}{ }^{2}-D_{i p 2} w_{p 2} \theta_{p 2}+\frac{1}{2} D_{i p 3} \theta_{p 2}{ }^{2}
\end{aligned}
$$
ここで,

$$
D_{i p 1}=k_{b 12}+k_{c 12}+k_{c 22}
$$

$$
\begin{aligned}
& D_{i p 2}=k_{c 12} L_{12}+k_{c 22} L_{22} \\
& D_{i p 3}=k_{b 22}+k_{c 12} L_{12}{ }^{2}+k_{c 22} L_{22}{ }^{2}
\end{aligned}
$$

次に, ディスクとパッド間の面圧分布の変動の定式化に ついて考える。上で述べたようにディスクとパッド間の面 圧分布の変動は，摩擦面の接触剛性を変動させる，文献 21$)$ によれば, パッドの $z$ 方向の圧縮変形量 $h_{p}$ と接触面圧 $p$ の 関係は次式で表される。

$$
p=k_{0} h_{p}+k_{1} h_{p}^{2}
$$

ここで， $k_{0}, k_{1}$ はともにパッドの材料物性で決まる定数 ${ }^{21}$ 22) であ る.さらに, 圧縮変形量 $h_{p}$ と接触面圧 $p$ の変化量をそれぞれ $\Delta h_{p}$, $\Delta p$ とし, $\Delta h_{p}$ は $h_{p}$ に比べて十分に小さいとすると, $\Delta h_{p}$ とブレ 一キ鳴き発生の原因である摩擦力変動を生じさせる $\Delta p$ の関係は 次式となる. 


$$
\Delta p=\left(k_{0}+2 k_{1} h_{p}\right) \Delta h_{p}=k_{p} \Delta h_{p}
$$

ここで, 上式において $k_{p}$ を次式のように定義している.

$$
k_{p}=k_{0}+2 k_{1} h_{p}
$$

上式より， $k_{p}$ は，ブレーキ鳴き発生時の接触剛性を表して おり, パッドの圧縮変化量 $h_{p}$ に伴い変化することがわかる.

他方, パッドは, ディスクと接触する摩擦材と, その摩 擦材を固定する裏金で構成されている。乗用車用ディスク ブレーキでは, 裏金は厚さ $5 \mathrm{~mm}$ 程度の冷間圧延鋼板を用い, 摩擦材ヤング率は, 裏金の $1 / 8$ 程度である。また, 安定し た制動力を発生させるために，キャリパは，パッドをディ スクに押付ける際に, 摩擦材の全面が接触し, かつ裏金の $z$ 方向の曲げ変形を極力小さくするように設計されている. このため, 図 3 で示すように, 裏金は剛体運動し, それに より摩擦材が $z$ 方向に圧縮されるため, パッドの変形量 $h_{p}$ は， $x$ 方向に変化し，その変化は線形となるように拘束さ れることになる。これに対して, 図 1 で示すパッドの $y$ 方 向の接触面圧は, 図 3 で示寸摩擦力モーメント $M_{x}$ の影響を 受けないため均一とする.

以上の考察より，図 1 に示す簡易モデルでは, パッドの 接触面形状が， $y$ 軸に対して刘称であることから $h_{p}$ は次式 で表されることになる

$$
h_{p}=A_{h} x+\bar{h}_{p}
$$

ここで, 図 4 に示すように, $\bar{h}_{p}$ は均一接触面圧時のパッド の $z$ 方向変形量, $A_{h}$ は $x$ 方向のパッド変形量の変動勾配を 表す定数である。よって，接触岡性 $k_{p}$ は，式(21)，（22）よ り次式となる。

$$
k_{p}=k_{0}+2 k_{1}\left(A_{h} x+\bar{h}_{p}\right)=A_{k} x+\bar{k}_{p}
$$

ここで,

$$
\begin{aligned}
& A_{k}=2 k_{1} A_{h} \\
& \bar{k}_{p}=k_{0}+2 k_{1} \bar{h}_{p}
\end{aligned}
$$

としている.上式より， $A_{k}$ は $k_{p}$ の $x$ 方向の変動勾配， $\bar{k}_{p}$ は パッド変形量 $\bar{h}_{p}$ における接触剛性を表している. また, 裏 金の動きは, 図 3 に示すように変動するため, 接触面の範 囲を $-l_{p} \leq x \leq l_{p}$ とすると, $A_{k}$ は以下の範囲で変動する.

$$
-\frac{\bar{k}_{p}}{l_{p}} \leq A_{k} \leq \frac{\bar{k}_{p}}{l_{p}}
$$

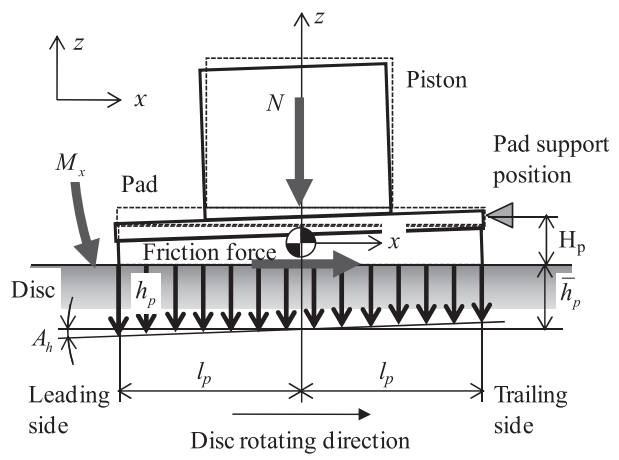

Fig. 4 Deformation at applying friction force
ここで, 設計変数と摩擦面の接触剛性の変動勾配の関係を 明確化するため, 設計諸元に依存しない正規化された設計 評価尺度として, 接触剛性の変動勾配を表す係数 $\eta$ を新た に提案し， $A_{k}$ を以下のように表わす.

$$
A_{k}=\eta \frac{\bar{k}_{p}}{l_{p}}, \quad-1 \leq \eta \leq 1
$$

これにより, $\eta=0$ で接触剛性が均一, つまり接触面圧が均 一な状態を, $\eta=1$ でパッドのリーディング側端部の接触剛 性が 0 , つまり, リーディング側端部の接触面圧は 0 の状態 を， $\quad \eta=-1$ で逆にトレーリング側端部の接触面圧が 0 の状 態を表すことができる。 また，以上の結果から $k_{p}$ は $\eta$ の関 数として表現できることがわかる.

次に, ブレーキ鳴きの発生要因となるディスクとパッド間の摩 擦力変化を表現する式を導く，いま，単位面積当たりの接触剛性 を, それぞれ， $k_{p 1}, k_{p 2}$ とし, それぞれの, 接触岡性の変動勾配 係数を $\eta_{i}(i=1,2)$ と表す. このとき, アウターパッド, インナー パッドとディスクの接触面の $z$ 方向の相対変位によって生ずる接 触面圧の変動 $\bar{F}_{z p 1}, \bar{F}_{z p 2}$ は, 次式となる.

$$
\begin{aligned}
& \bar{F}_{z p 1}=-k_{p 1}\left(s_{1}-w_{d}\right) \\
& \bar{F}_{z p 2}=-k_{p 2}\left(s_{3}-w_{d}\right)
\end{aligned}
$$

ここで

$$
\begin{aligned}
& s_{1}=w_{p 1}-\left(L_{31}-r \sin \varphi\right) \theta_{p 1} \\
& s_{3}=w_{p 2}-\left(L_{32}-r \sin \varphi\right) \theta_{p 2}
\end{aligned}
$$

この接触面圧の変動により摩擦力の変化が生じ，これにより，ア ウターパッド, インナーパッドに摩擦力モーメント $\bar{M}_{\theta p 1}, \bar{M}_{\theta p 2}$ が作用する．いま，ディスクとアウターパッド，インナーパッド 間の摩擦係数を，それぞれ $\mu_{p 1}, \mu_{p 2}$ とすると， $\bar{M}_{\theta p 1}, \bar{M}_{\theta p 2}$ は 次式となる.

$$
\begin{aligned}
& \bar{M}_{\theta p 1}=-H_{p 1} \mu_{p 1} \bar{F}_{z p 1} \cos \varphi \\
& \bar{M}_{\theta p 2}=-H_{p 2} \mu_{p 2} \bar{F}_{z p 2} \cos \varphi
\end{aligned}
$$

したがって，簡易モデルにおける自由度 $w_{p 1}, \theta_{p 1}, w_{p 2}, \theta_{p 2}$, $w_{d}$ に関する一般化力 $Q_{1 n c}, Q_{2 n c} ， Q_{3 n c} ， Q_{4 n c} ， Q_{5 n c}$ は，それぞ れ次式となる.

$$
\begin{aligned}
& Q_{1 n c}=\int_{r_{1}}^{r_{2}} \int_{-\varphi_{p 1}}^{\varphi_{p 1}}\left(\bar{F}_{z p 1} \frac{\partial s_{1}}{\partial w_{p 1}}\right) r d \varphi d r \\
& Q_{2 n c}=\int_{r_{1}}^{r_{2}} \int_{-\varphi_{p 1}}^{\varphi_{p 1}}\left(\bar{F}_{z p 1} \frac{\partial s_{1}}{\partial \theta_{p 1}}+\bar{M}_{\theta p 1}\right) r d \varphi d r \\
& Q_{3 n c}=\int_{r_{1}}^{r_{2}} \int_{-\varphi_{p 1}}^{\varphi_{p 1}}\left(\bar{F}_{z p 2} \frac{\partial s_{3}}{\partial w_{p 2}}\right) r d \varphi d r \\
& Q_{4 n c}=\int_{r_{1}}^{r_{2}} \int_{-\varphi_{p 1}}^{\varphi_{p 1}}\left(\bar{F}_{z p 2} \frac{\partial s_{3}}{\partial \theta_{p 2}}+\bar{M}_{\theta p 2}\right) r d \varphi d r \\
& Q_{5 n c}=\int_{r_{1}}^{r_{2}} \int_{-\varphi_{p 1}}^{\varphi_{p 1}}\left(\bar{F}_{z d}\right) r d \varphi d r
\end{aligned}
$$

式(7)〜 (10), 式(14), (15)より, 次式に示寸ラグランジュア 
Table 1 Design parameter values

\begin{tabular}{c|c||c|c}
\hline $\begin{array}{c}\text { Design } \\
\text { parameter }\end{array}$ & Value & $\begin{array}{c}\text { Design } \\
\text { parameter }\end{array}$ & Value \\
\hline \hline$L_{11}, L_{12}$ & $0.0265 \mathrm{~m}$ & $I_{p 1}, I_{p 2}$ & $5.57 \times 10^{-4} \mathrm{~kg} \mathrm{~m}$ \\
\hline$L_{21}, L_{22}$ & $0.0825 \mathrm{~m}$ & $k_{b 11}, k_{b 12}$ & $3.33 \times 10^{7} \mathrm{~N} / \mathrm{m}$ \\
\hline$L_{31}, L_{32}$ & $0.0595 \mathrm{~m}$ & $k_{b 21}, k_{b 22}$ & $1.53 \times 10^{4} \mathrm{~N} \mathrm{~m} / \mathrm{rad}$ \\
\hline$H_{p 1}, H_{p 2}$ & $0.0175 \mathrm{~m}$ & $k_{c 11}, k_{c 12}$ & $3.20 \times 10^{6} \mathrm{~N} / \mathrm{m}$ \\
\hline$\varphi_{p 1}, \varphi_{p 2}$ & $25 \mathrm{deg}$ & $k_{c 21}, k_{c 22}$ & $3.20 \times 10^{6} \mathrm{~N} / \mathrm{m}$ \\
\hline$m_{p 1}, m_{p 2}$ & $0.47 \mathrm{~kg}$ & $N$ & 3 \\
\hline$r_{1}$ & $0.0905 \mathrm{~m}$ & $E$ & $1.60 \times 10^{11} \mathrm{~N} / \mathrm{m}^{2}$ \\
\hline$r_{2}$ & $0.167 \mathrm{~m}$ & $\rho$ & $7.80 \times 10^{3} \mathrm{~kg} / \mathrm{m}^{3}$ \\
\hline$H_{d}$ & $0.0187 \mathrm{~m}$ & $v$ & 0.3 \\
\hline
\end{tabular}

ン $L$ を得る.

$$
L=T_{d}+T_{p 1}+T_{p 2}-V_{d}-V_{p 1}-V_{p 2}
$$

これに, 次式に示すラグランジェの運動方程式に代入して整理す れば, 次式の運動方程式を得る.

$$
\mathbf{M} \ddot{\mathbf{u}}+\left(\mathbf{K}_{s}+\mathbf{K}_{p}\right) \mathbf{u}=\mathbf{f}
$$

ここで， $\mathbf{u}$ はシステムの変位ベクトル， M は質量マトリク ス， $\mathbf{K}_{s}, \mathbf{K}_{p}$ は剛性マトリクス, $\mathbf{f}$ は起振力ベクトルであ る。なお，簡易モデルの自由度は，ディスク変位 $w_{d}$ を式(5)に 示すように変数分離し, 定式化したことから全 5 自由度となる.

式 (40)の固有值 $\lambda$ を求めると, 固有值 $\lambda$ が複素数となる. そ の $\lambda$ の実部を $\alpha, \omega$ を虚部とする. $\lambda$ の実部 $\alpha$ が正となる場合, ブレーキシステムにおいて, 角振動数 $\omega$ とする自励振動, 寸なわ ちブレーキ鳴きが発生する.

\section{3. ブレ一キ鳴き低減のための最適設計法}

\section{1 不確定因子のブレーキ鳴き性能への影響}

実際のブレーキ鳴きの発生状況は, ブレーキの使用条件等で変 化する. 特に, ディスクとアウターおよびインナーパッド間の摩 擦係数 $\mu_{p i}(i=1,2)$ と, 接触剛性を表わ寸単位面積当たりのばね定 数 $k_{p i}(i=1,2)$, さらに, 接触岡性の変動勾配係数 $\eta_{i}(i=1,2)$ は, ディスクに加えられる制動力や, パッドの温度, 摩耗の度合いに より変化し，それぞれを特定の值に設定することは非常に困難で あるにもかかわらず，ブレーキ鳴きの発生状況に影響を及ぼすと 考えられる. このことから, 以下に示寸解析では, 摩擦係数 $\mu_{p i}$, 接触剛性 $k_{p i}$, 接触岡性の変動勾配係数 $\eta_{i}$ の変化しうる值に対し て,ブレーキ鳴き性能の頑健性を評価し, 設計する手法を考える.

まず，前章で示した簡易モデルを用い，後述の最適設計問題の 定式化の考察の基礎として, これらの変動パラメータのブレーキ 鳴き性能への影響について確認する。ここでは, アウターパッド とインナーパッドの材質は同一, アウターパッドとインナーパッ ドの摩耗状態が等しくなる対向型キャリパを用いたブレーキシス テムを対象とし, アウター側とインナー側のパッドの摩擦係数, 接触岡性, 接触岡性の変動勾配係数は等しいとする. 表 1 に数值 解析に必要な設計パラメータの值を示す.

最初に, 摩擦係数 $\mu_{p i}$ の変動がブレーキ鳴き性能に及ぼす影響 を確認する. 接触岡性を $\bar{k}_{p i}=4.0 \times 10^{10} \mathrm{~N} / \mathrm{m}$, 接触剛性の変動勾 配係数を $\eta_{i}=0.93$ の一定值とし, 摩擦係数 $\mu_{p i}$ を変化させた場合 の複素固有值 $\lambda_{j}(j=1,2, \cdots, 5)$ の変化を図 5 に示寸. なお, この 簡易モデルを用いて固有值解析を行うと，5つの固有值が得られ るが, ここでは, 固有值の虚部 $\omega_{j}$ の大きい順に固有值の順番付け

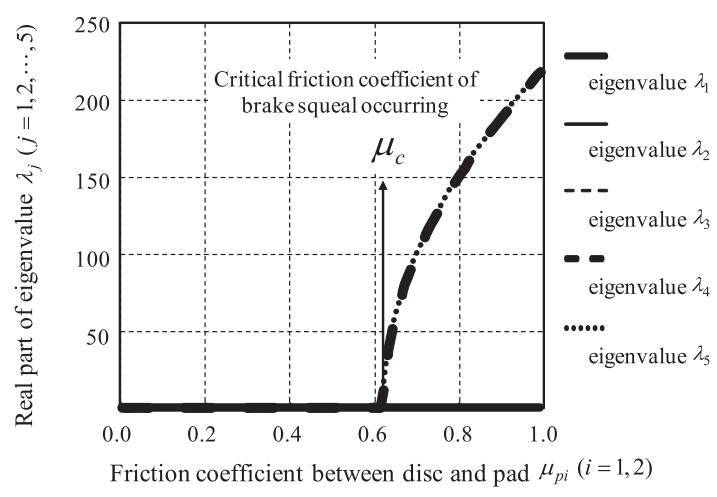

Fig. 5 Relationship between $\mu_{p i}$ and real part of eigenvalue

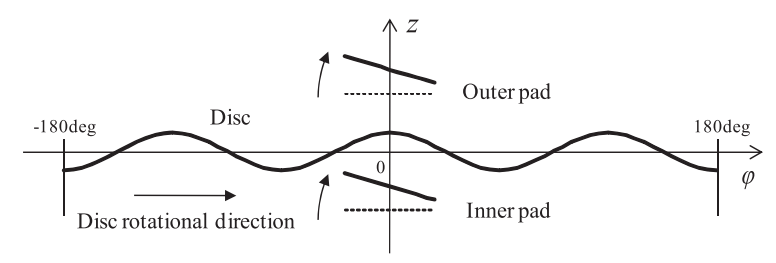

Fig. 6 Disc and pads vibration modes

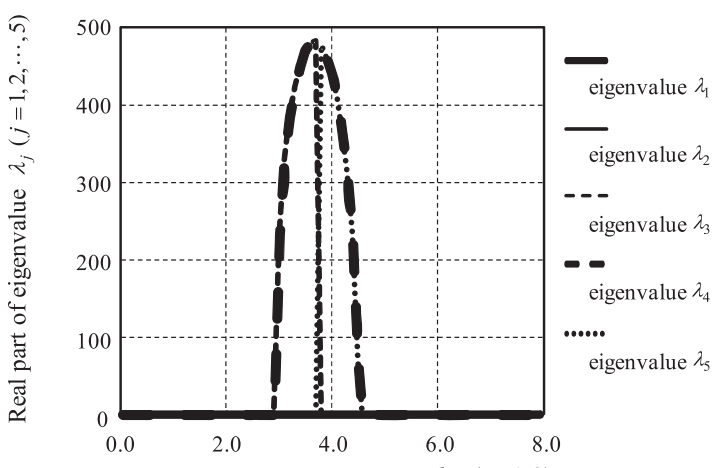

Contact stiffness between disc and pad $k_{p i}(i=1,2) \quad \times 10^{10} \mathrm{~N} / \mathrm{m}$

Fig. 7 Relationship between $k_{p i}$ and real part of eigenvalue

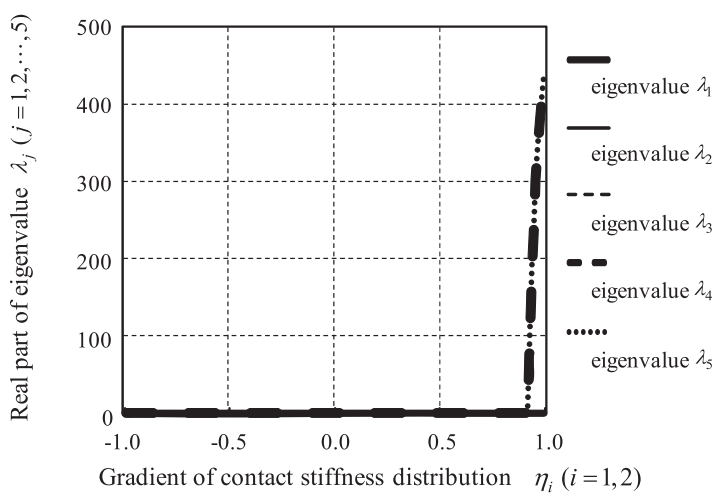

Fig.8 Relationship between $\eta_{i}$ and real part of eigenvalue

をすることにする．図 5 から，5つの固有值 $\lambda_{j}$ の実部 $\alpha_{j}$ は, 摩 擦係数が小さいときはゼロで, 摩擦係数 $\mu_{p i}$ が 0.62 を超えたとき に $\lambda_{4}, \lambda_{5}$ の実部 $\alpha_{4}, \alpha_{5}$ が正となり, ブレーキ鳴きが発生する. 図 6 に摩擦係数 $\mu_{p i}$ が 0.7 ときの $\lambda_{4}$ および $\lambda_{5}$ の振動モードの実部 を示す．同図より，ブレーキ鳴きが，ディスクが 3 次曲げ，アウ 
ターおよびインナーパッドは主に剛体回転モードで発生すること がわかる.

次に, 接触岡性 $k_{p i}$ の変動がブレーキ鳴き性能に及ぼす影響を 確認する. 摩擦係数を $\mu_{p i}=0.7$, 接触剛性の変動勾配係数を $\eta_{i}=1.0$ とし, 接触岡性 $k_{p i}$ を変化させた場合の, 複素固有值 $\lambda_{j}$ の 実部 $\alpha_{j}$ の変化を図 7 に示寸. 図 7 から， $\lambda_{3}, \lambda_{4}$ の実部 $\alpha_{3}, \alpha_{4}$ は， $\bar{k}_{p i}$ が $3.0 \times 10^{10} \mathrm{~N} / \mathrm{m} \sim 3.7 \times 10^{10} \mathrm{~N} / \mathrm{m}$ の範井で正となり， $\lambda_{4}$ ， $\lambda_{5}$ の実部 $\alpha_{4}, \alpha_{5}$ は, $\bar{k}_{p i}$ が $3.8 \times 10^{10} \mathrm{~N} / \mathrm{m} \sim 4.5 \times 10^{10} \mathrm{~N} / \mathrm{m}$ の範囲 で正となり，接触剛性については， $\bar{k}_{p i}$ が $3.0 \times 10^{10} \mathrm{~N} / \mathrm{m} \sim$ $4.5 \times 10^{10} \mathrm{~N} / \mathrm{m}$ の範囲においてのみブレーキ鳴きが発生するこ とがわかる.

最後に, 接触剛性の変動勾配係数 $\eta_{i}$ の変動がブレーキ鳴き性能 に及ぼす影響を確認する. 摩擦係数を $\mu_{p i}=0.7$, 接触剛性を $\bar{k}_{p i}=4.0 \times 10^{10} \mathrm{~N} / \mathrm{m}$ とし, 接触岡性の変動勾配係数 $\eta_{i}$ を変化させ た場合の複素固有值 $\lambda_{j}$ の実部 $\alpha_{j}$ の変化を図 8 に示す. 図 8 か ら $\lambda_{j}$ の実部 $\alpha_{j}$ は, 接触剛性の変動勾配係数 $\eta_{i}$ が小さいときはゼ 口で, 接触剛性の変動勾配係数 $\eta_{i}$ が 0.92 を超えたときに, $\lambda_{4}, \lambda_{5}$ の実部 $\alpha_{4}, \alpha_{5}$ が正となり, ブレーキ鳴きが発生している.

以上の結果から，これらの不確定なパラメータの変動に 対して頑健性の高いブレーキ鳴き最適設計法を構築する.

\section{2 最適設計問題の定式化}

環境要因などの不確定因子の変動に対してロバスト性の 高いシステムを導出するための最適設計の考え方として, ロバスト最適設計法 ${ }^{23)}$ がある。ロバスト最適設計の方法に は, 不確定因子の変動の確率分布を仮定して, 性能の劣化 の確率を規定する方法や, 性能の不確定因子に対する感度 を最小化することで, 不確定因子の変動による性能の劣化 を抑制する方法等があり, 問題に応じて適切な定式化を行 うことが求められる.

ブレーキシステムの構想設計では, 図 5，7，8で確認したよ うに, 摩擦係数 $\mu_{p i}$, 接触剛性 $k_{p i}$, 接触岡性の変動勾配係数 $\eta_{i}$ と いう, 不確定因子がどのように変動しても, ブレーキ鳴きが発生 しないことが要求される，そこで，これら不確定因子が取りうる すべての值 $0<\mu_{p i} \leq \mu_{\text {max }}, 0 \leq k_{p i} \leq k_{p \text { max }},-1 \leq \eta_{i} \leq 1$ に対して, ブレーキ鳴きが発生しないようロバス卜性を表した制約条件によ る定式化を行う。

まず, 摩擦係数 $\mu_{p i}$ あるいは接触剛性の変動勾配係数 $\eta_{i}$ につい ては， $\mu_{p i}, \eta_{i}$ が，臨界值 $\mu_{c} ， \eta_{c}$ を超えたときにブレ一キ鳴き が発生することから, 想定される範囲 $0<\mu_{p i} \leq \mu_{\max }, \quad-1 \leq \eta_{i} \leq 1$ の上限值よりも，ブレーキ鳴きが発生する臨界值が高くなるよう にすべきである，それには， $\mu_{p i}, \eta_{i}$ の上限值における複素固有 值の実部をゼロとしなければならない。これに対して, 接触岡性 については, 接触剛性が変動する範囲内 $0 \leq k_{p} \leq k_{p \text { max }}$ のすべてで, 複素固有值の実部 $\alpha_{j}=\operatorname{Re}\left(\lambda_{j}\right)$ がゼロとなる必要がある. ここで はさらに, ディスクの振動モードを示寸直径方向の節の数 $N$ に対 しても想定される範囲 $N \in N_{g}$ の寸べてで, 複素固有值の実部が ゼロとする.

以上の理由から，不確定因子の最悪值に対して，ブレーキ鳴き が発生しないような設計解を求めることができるよう, 制約条件 を以下のように定式化する.

$$
h=\left.\max _{\substack{0 \leq k_{k_{i}} \leq k_{\text {pmax }} \\ N \in N_{g}}}\left[\alpha_{j}=\operatorname{Re}\left(\lambda_{j}\right)\right]\right|_{\mu_{p_{i}}=\mu_{\max }, \eta_{i}=1}=0
$$

ここで， $h$ は等式制約を示し， $N_{g}$ は想定される直径方向の節の 数 $N$ の集合であり, $k_{p \max }$ は接触剛性の上限值, $\mu_{\max }$ は摩擦係数
の上限值である.

また一方で, ディスクブレーキの制動力とパッドの寿命を確保 するため, パッドの寸法は大きくすることが望まれる. そこで, 式(41)に示すように，パッドの中心角を表す変数 $\varphi_{p i}(i=1,2)$ を 目的関数 $f$ として, 支持点 $L_{1 i}, L_{2 i}$, そして, キャリパとパッ ドの接触岡性 $k_{b 1 i}, k_{b 2 i}, \quad k_{c 1 i}, \quad k_{c 2 i}$ を設計変数とし, $\varphi_{p i}$ の最大 化を図る. さらに, 制約条件として, 各設計諸元に上限值と下限 值を式(43)から(45)で示すように設け, 最適設計問題を，以下の ように定式化する.

$$
\underset{\varphi_{p i}, L_{i}, L_{2 i}, k_{b i}, k_{b 2 i}, k_{c i}, k_{c 2 i}}{\operatorname{maximize}} f=\varphi_{p i} \quad(i=1,2)
$$

制約条件：

$$
\begin{aligned}
& h=\left.\max _{\substack{0 \leq k_{p i} i k_{\max } \\
N \in N_{g}}}\left[\alpha_{j}=\operatorname{Re}\left(\lambda_{j}\right)\right]\right|_{\mu_{\mu_{i}}=\mu_{\max }, \eta_{i}=1}=0 \\
& L_{1 i}{ }^{L} \leq L_{1 i} \leq L_{1 i}{ }^{U}, \quad L_{2 i}{ }^{L} \leq L_{2 i} \leq L_{2 i}{ }^{U} \\
& k_{b 1 i}{ }^{L} \leq k_{b 1 i} \leq k_{b 1 i}{ }^{U}, \quad k_{b 2 i}{ }^{L} \leq k_{b 2 i} \leq k_{b 2 i}{ }^{U} \\
& k_{c 1 i}{ }^{L} \leq k_{c 1 i} \leq k_{c 1 i}{ }^{U}, \quad k_{c 2 i}{ }^{L} \leq k_{c 2 i} \leq k_{c 2 i}{ }^{U}
\end{aligned}
$$

\section{4. 数 值 解 析}

\section{1 パッドの大きさを設計変数とした場合}

まず，前章で示した最適設計問題を，パッドの大きさを表す扇 型形状の中心角 $\varphi_{p i}$ の夕を設計変数として解く. なお, インナー 側とアウター側のパッドは，共に $y$ 軸について刘称で同じ中心角 $\varphi_{p}$ となることとした. また, 最適化手法を適用する際の数值安定 性を確保するため, 式(41)の制約条件を，次式のように緩和して 計算を行った.

$$
h^{\prime}=\left.\max _{\substack{0 \leq k_{p} \leq k_{\max } \\ N \in N_{g}}}\left[\alpha_{j}=\operatorname{Re}\left(\lambda_{j}\right)\right]\right|_{\mu_{\mu=\mu_{\max }, \eta=1}}-\varepsilon \leq 0
$$

ここで, $\varepsilon$ は微小な正の值で, ここでは $\varepsilon=1.0$ とした．また，パ ッドの中心角 $\varphi_{p}$ 以外の設計変数は定数とし表 1 と同じ值を用い た.

他方, 図 5，7，8に示すように， $\alpha_{j}$ の勾配変化は， $\alpha_{j}$ が 0 から実数值に遷移寸る近傍で急であり, 通常の局所探索法では数 值的に不安定となりやすいため, 最適化は遺伝的アルゴリズムに より行った.このとき, 設計変数はグレイコードによって表現し, トーナメント選択法を用いた. その他の設計諸元は, 表 1 に示寸 ものと同じ值を用い, さらに, 摩擦係数の上限值 $\mu_{\max }=0.7$, 接 触剛性の上限值 $k_{p \max }=8.0 \times 10^{10} \mathrm{~N} / \mathrm{m}$, 想定されるディスク振動モ

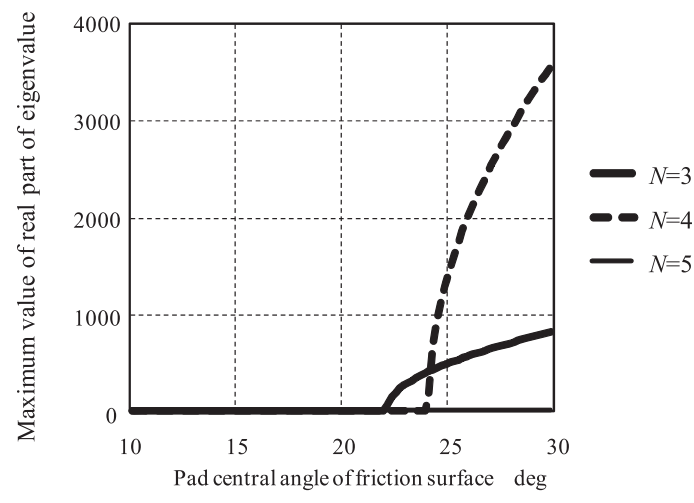

Fig. 9 Maximum value of real part of eigenvalue 
ードの直径方向の節の数 $N_{g}=\{3,4,5\}$ とした.

このとき, 最適なパッド中心角は, $\varphi_{p}=22.24$ となった. また, $N$ を 3, 4, 5 としたそれぞれの場合の, パッド中心角の大きさ $\varphi_{p}$ と, 複素固有值の実部の最大值 $g$ の関係を図 9 に示す, パッド中 心角の大きさ $\varphi_{p}$ を 22.24 度以上にすると, ディスクが, 直径方向 に 3 つ節をもつ曲げモードすなわち $N=3$ で振動するブレーキ 鳴きが発生することが図 9 からもわかる.

\section{2 実験検証}

ここでは，提案した簡易モデルと最適設計法の妥当性を 検証するために, 前節の計算結果と実験結果の比較・検討 を行った結果を示寸. 図 10 に実験装置（明電舎, 特注品）を 示す. 図に示すように, ディスクとキャリパで構成されるブレー キシステムを, 実験装置に固定されたサスペンション部品に取り 付けた. そして, パッドの中心角 $\varphi_{p}$ を 23 度とし, 制動前の パッド温度を $40^{\circ} \mathrm{Cから} 200^{\circ} \mathrm{C}$ 間で 11 水準, 制動時にキャリ パに負荷する油圧を $0.2 \sim 2.5 \mathrm{MPa}$ の間で 10 水淮とし，その 組合せからなる 110 条件の制動を 54 回繰り返し, ブレーキ

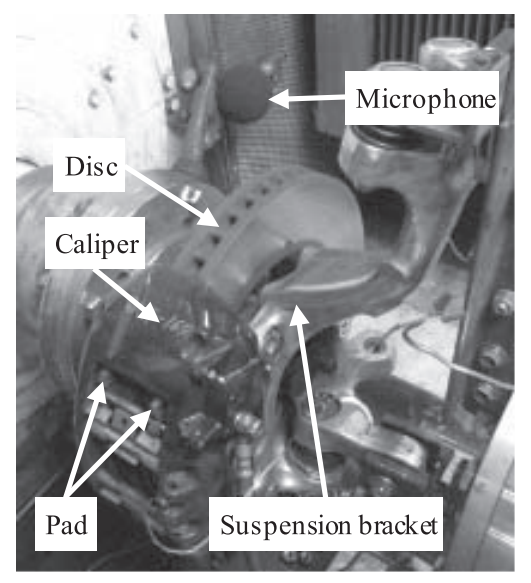

Fig. 10 Experimental system of squeal evaluation

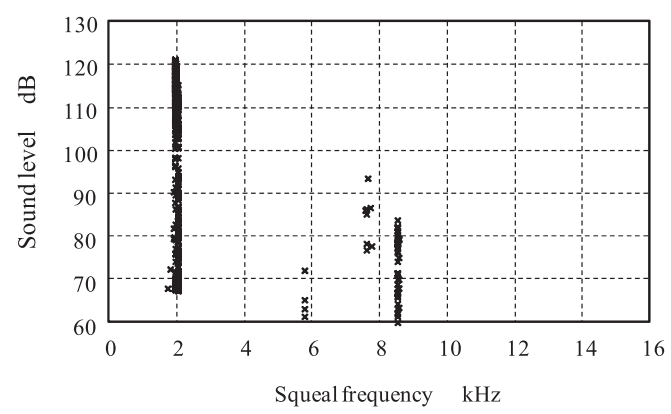

Fig. 11 Squeal evaluation result

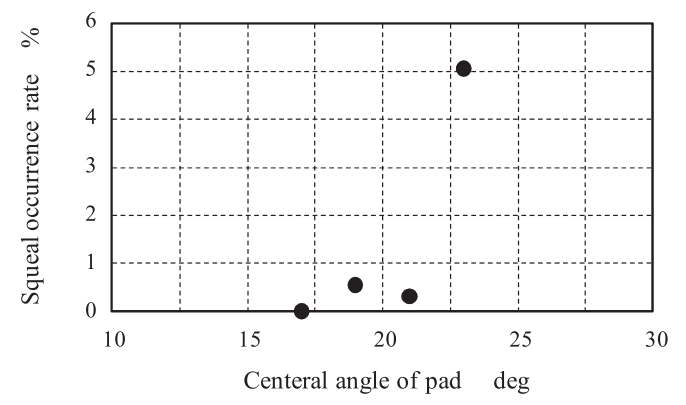

Fig. 12 Squeal occurrence rate for pad central angle
鳴き発生時の音圧と振動数を解析，記録する実験を行った。 図 11 に実験結果を示す。図 11 から,ブレーキ鳴きは, 1.8 $\sim 2.0 \mathrm{kHz}, 5.8 \mathrm{kHz}$ と $7.6 \sim 8.5 \mathrm{kHz}$ の振動数で発生した.

また, 数值解析結果の妥当性を確認寸るために, ブレーキ鳴き 発生時のディスクの面外方向の振動モードを ESPI (Electric Speckle Pattern Interferometry)を用いて計測し, 解析した. その結 果, $\quad 1.8 \sim 2.0 \mathrm{kHz}$ のブレーキ鳴きは，ディスクが直径方向に $3 つ$ の節をもつ曲げモード, 寸なわち $N=3$ で振動していることがわ かり, 図6で示した数值解析上のブレーキ鳴き発生時の振動モー ドと特徵が一致していることから, 図 $5 ， 7 ， 8 ， 9$ で示した数 值解析結果は，実験結果と整合することが確認できた．

次に, 最適結果の妥当性を確認するために, パッドの中心角 $\varphi_{p}$ のブレーキ鳴き性能への影響を確認した。 寸なわち, ブ レーキ鳴きが発生しなくなる方向でである, $\varphi_{p}$ が 23 度, 21 度, 19 度, 17 度の 4 水準のパッドを準備し, それぞれにつ いて同様の実験を行った。図 12 に $\varphi_{p}$ が 23 度, 21 度, 19 度, 17 度で発生したブレーキ鳴きで, 振動数 $1.8 \sim 2.0 \mathrm{kHz}$ の発生確率を示す.

図 12 から, パッドの中心角 $\varphi_{p}$ を 23 度にするとブレーキ 鳴きの発生率が増加していることから，ブレーキ鳴きが発 生するパッドの中心角 $\varphi_{p}$ の臨界值は 23 度であることがわかった. また，図 9 に示すように，最適化により得られたブレーキ鳴き が発生するパッドの中心角の臨界值は, 22.24 度で, 実験結 果とほぼ一致しており, 最適化の方法が妥当であることを 確認することができた.

\section{3 ブレーキシステムの構想設計への展開}

次に, アウター側およびインナー側それぞれにおける，パッド の中心角 $\varphi_{p i}$, 支持点 $L_{11}, L_{21}, L_{12}, L_{22}$, そして, キャリ パとパッドの接触岡性 $k_{b 11}, k_{b 12}, k_{b 21}, k_{b 22}, k_{c 11}, k_{c 12}, k_{c 21}$, $k_{c 22}$ を設計変数とした場合について最適解を求めた. ただし, 寸 べての変数について, アウター側と, インナー側で同じ值をとる こととし, アウター側とインナー側を区別する添え字を省略して $\varphi_{p}, L_{1}, L_{2}, k_{b 1}, k_{b 2}, k_{c 1}, k_{c 2}$ と表すこととする.なお, 設計変数の側面制約は，表 2 のように設定した．また，4.1 節の 数值計算と同様に, $\mu_{\text {max }}=0.7, k_{p \max }=8.0 \times 10^{10} \mathrm{~N} / \mathrm{m}$, $N_{g}=\{3,4,5\}$ とし, 同じ遺伝的アルゴリズムを用いて最適化を図 った. 表 $3 に$ 最適解を示す. この結果から, 設計諸元を調整する ことで, パッドの中心角 $\varphi_{p}$ を 24.48 度まで広げてもブレーキ鳴き を抑制することができることがわかった，さらに，最適解の設 計諸元において， $N$ を $3 ， 4 ， 5$ と，それぞれ固定したそれぞれ の場合の, パッドの中心角 $\varphi_{p}$ と, 複素固有值の実部の最大值 $h$ の関係を, 表 3 で示した設計諸元を用いた場合について 図 13 に示す。図 9 と比較すると, 図 13 では, ブレーキ鳴 きが発生するパッドの大きさの臨界值が高い值に移動して

\begin{tabular}{c|c|c}
\multicolumn{3}{c}{ Table 2 Side constraints } \\
\hline $\begin{array}{c}\text { Design } \\
\text { variable }\end{array}$ & Lower limit & Upper limit \\
\hline$L_{1}$ & $0.02 \mathrm{~m}$ & $0.04 \mathrm{~m}$ \\
\hline$L_{2}$ & $0.079 \mathrm{~m}$ & $0.099 \mathrm{~m}$ \\
\hline$\varphi_{p}$ & $20 \mathrm{deg}$ & $30 \mathrm{deg}$ \\
\hline$k_{b 1}$ & $1.67 \times 10^{7} \mathrm{~N} / \mathrm{m}$ & $6.66 \times 10^{7} \mathrm{~N} / \mathrm{m}$ \\
\hline$k_{b 2}$ & $0.765 \times 10^{4} \mathrm{~N} \mathrm{~m} / \mathrm{rad}$ & $3.06 \times 10^{4} \mathrm{~N} \mathrm{~m} / \mathrm{rad}$ \\
\hline$k_{c 1}$ & $1.60 \times 10^{6} \mathrm{~N} / \mathrm{m}$ & $6.40 \times 10^{6} \mathrm{~N} / \mathrm{m}$ \\
\hline$k_{c 2}$ & $1.60 \times 10^{6} \mathrm{~N} / \mathrm{m}$ & $6.40 \times 10^{6} \mathrm{~N} / \mathrm{m}$ \\
\hline
\end{tabular}


Table 3 Optimum solution

\begin{tabular}{c|c}
\hline Design variable & Optimum solution \\
\hline$L_{1}$ & $0.0299 \mathrm{~m}$ \\
\hline$L_{2}$ & $0.0795 \mathrm{~m}$ \\
\hline$\varphi_{p}$ & $24.48 \mathrm{deg}$ \\
\hline$k_{b 1}$ & $1.67 \times 10^{7} \mathrm{~N} / \mathrm{m}$ \\
\hline$k_{b 2}$ & $7.65 \times 10^{3} \mathrm{~N} \mathrm{~m} / \mathrm{rad}$ \\
\hline$k_{c 1}$ & $5.83 \times 10^{6} \mathrm{~N} / \mathrm{m}$ \\
\hline$k_{c 2}$ & $6.40 \times 10^{6} \mathrm{~N} / \mathrm{m}$ \\
\hline
\end{tabular}

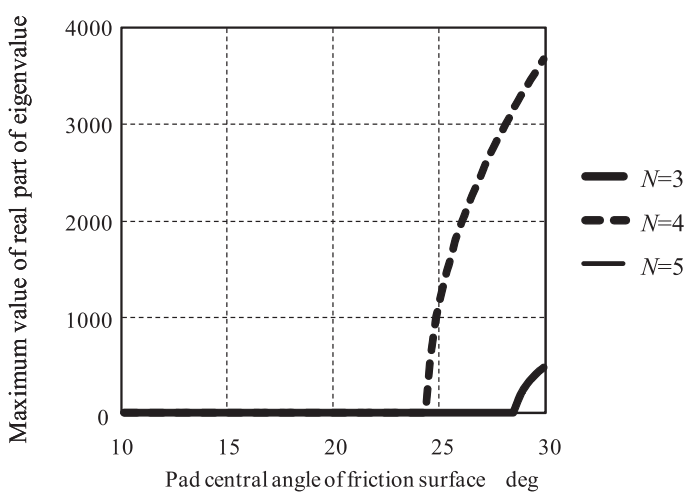

Fig. 13 Maximum value of real part of eigenvalue for optimal design

おり, 求めた最適解を用いることで， $N=3$ の振動モードの ブレーキ鳴きを低減できることがわかった。しかし，得ら れた最適解では, $N=4$ の振動モードのブレーキ鳴きについ ては，他の設計変数を検討する必要があることがわかった． さらに, $N=5$ の振動モードのブレーキ鳴きは発生しないこ ともわかった。

\section{5. 結 言}

本研究では, FOA の考え方に基づき，ディスクブレーキ 鳴き低減を目指した構想設計法について，ディスクとパッ ドの間の面圧分布の変動を考慮した最適設計法を開発した。 得られた結果を以下に示す.

(1) FOA の考え方のもと，構想設計段階において，ブレー キ鳴きの発生メカニズムが理解でき，設計指針を得るこ とが容易な簡易モデルを構築した。さらに，新たな設計 指針得るために必要となる尺度として，接触剛性の変動 勾配を表す係数 $\eta$ を提案した。

（2）簡易モデルを用いて，数值解析により，不確定因子で ある摩擦係数，接触岡性，さらに接触岡性の変動勾配係数と ブレーキ鳴きの性能の関係を明確化した。

（3）不確定因子である摩擦係数，接触岡性，さらに接触岡性の 変動勾配係数の変動に関してブレーキ鳴きを発生しないロバ ストなシステムを得るための最適化問題を定式化した.

（4） 2 つの実設計問題に対して，最適化を図ることより，不確 定因子に対して頑健な最適解を得ることができた.さらに, 実験検証により，得られた最適解の妥当性を検証した。 これ らより，本報で提案する方法論は，不確定因子に関してロバ ストなブレーキシステムの構想設計案を提供できることがわ
かった.

\section{参 考 文 献}

1) H. Nishigaki et al.: First Order Analysis for Automotive Body Structure Design, Proceedings of DECT'00 ASME2000 Design Engineering Technical Conference and Computer and Information in Engineering Conference, DECT2000/DAC-14533, (2000) 1.

2) H. Blok: Fundamental Mechanical Aspects of Boundary Lubrication, SAE Journal, 46, (1940) 54.

3) A. Watari and T. Sugimoto: Vibrations Caused by Dry Friction, Transactions of the Japan Society of Mechanical Engineers, 29, 200, (1963-4) 769 (in Japanese)

4) GX. Chen et al.: Experimental Investigation into Squeal under Reciprocating Sliding, Tribology International, 36, 12(2003) 961

5) GX. Chen and Z. R. Zhou: Experimental Observation of the Initiation Process of Friction-induced Vibration under Reciprocating Sliding Condition, Wear, 259, 1-6(2005) 277.

6) N. Millner: An Analysis of Disk Brake Squeal, SAE , 780332, (1978) 1 .

7) N. M. Kinkaid, O. M. O'Reilly and P. Papadopoulos: Review Automotive Disc Brake Squeal, Journal of Sound and Vibration, 267, 1(2003) 105.

8) H. Okamura and M. Nishiwaki: Study on Brake Noise : 1st Report, On Drum Brake Squeal, Transactions of the Japan Society of Mechanical Engineers, Series C, 54, 497, (1988-1) 166 (in Japanese).

9) H. Harada et al.: Study of Brake Noise : 2nd Report, On Disc Brake Squeal, Transactions of the Japan Society of Mechanical Engineers, Series C, 55, 512 (1989-4) 932 (in Japanese).

10) M. Nishiwaki: Study of Brake Noise : 5th Report, Generalized Theory of Brake Noise, Transactions of the Japan Society of Mechanical Engineers, Series C, 56, 527 (1990-7) 138 (in Japanese).

11) A. Sueoka et al.: Squeal of a Disk Brake Floating Type for Cars : 1st Report, Relationship between Occurrence of Squeal and Contact Region between Rotor and Pads in Experiment, Transactions of the Japan Society of Mechanical Engineers, Series C, 67, 658 (2001-6) 1719 (in Japanese)

12) A. Sueoka, T. Ryu and K. Shirozu: Squeal of a Disk Brake Floating Type for Car : 2nd Report, Analytical Results, Transactions of the Japan Society of Mechanical Engineers, Series C, 67, 658 (2001-6) 1727 (in Japanese)

13) A. Sueoka and T. Ryu: Noise and Vibration in Disk Brake for Automotive, Journal of the Japanese Society of Tribologists, 48, 1(2003) 36 (in Japanese).

14) Y. Nakano, T. Ryu and A. Sueoka: Squeal of Rigid Type Disk Brake for Car, Transactions of the Japan Society of Mechanical Engineers, Series C, 70, 700 (2004-12) 3398 (in Japanese).

15) K. Ohta et al.: Study on the Disk Brake Squeal : Simulation Using Modal Analysis Technique and Experiments, Transactions of the Japan Society of Mechanical Engineers, Series C, 50, 457, (1984-6) 1585.

16) U. Wagner, D. Hochlenert and P. Hagedorn: Minimal Models for Disk Brake Squeal, Journal of Sound and Vibration, 302, 3(2007) 527.

17) G. D. Liles: Analysis of Disk Brake Squeal Using Finite Element Methods, SAE, 891150, (1989) 1.

18) I. Kido, T. Kurahachi and M. Asai: A Study on Low-Frequency Brake Squeal Noise, SAE, 960993, (1996) 1.

19) C. Chung et al.: A New Analysis Method for Brake Squeal Part1: Theory for Modal Domain Formulation and Stability Analysis, SAE , 2001-01-1600, (2001) 1.

20) T. Matsushima, K. Izui, S. Nishiwaki: A Conceptual Design Mrthod of Disc Brake Systems for Reducing Brake Squeal -Construction of a Design Criterion Using Simplified Model Based on the Concept of First Order Analysis-, J. Jpn. Soc. Precis. Eng., 76, 8 (2010) 973 (in Japanese)

21) Y. Oura et al.: Surface Contact Analysis Model for Squeal on Disk Brake, Transactions of the Japan Society of Mechanical Engineers, Series C, 73, 731, (2007-7) 0236 (in Japanese).

22) Y. Oura, Y. Kurita and Y. Matsumura: Influence of Dynamic Stiffnes in Contact Region on Disk Brake Squeal, Transactions of the Japan Society of Mechanical Engineers, Series C, 73, 731, (2007-7) 0237 (in Japanese).

23) H.- G.Beyer, B. Sendhoff: Robust Optimization - A comprehensive survey, Computer Methods in Applied Mechanics and Engineering, 196, 33, (2007) 3190. 